\title{
EVOLUTION OF POPULATION OF HUMAN SETTLEMENTS BETWEEN YEARS 1912 AND 2011 IN MEHEDINT,EAN DEPRESSION CORRIDOR AND SEVERIN DEPRESSION
}

\author{
Luca DIACONESCU* \\ University of Oradea, Doctoral School of Geography, 1 Universităţii St., 410087, Oradea, \\ Romania, e-mail: diaconesculuca@yahoo.ro
}

\begin{abstract}
Citation: Diaconescu, L. (2019). Evolution of Population of Human Settlements Between Years 1912 and 2011 in Mehedințean Depression Corridor and Severin Depression. Analele Universităţii din Oradea, Seria Geografie, 29(2), 106-113. https://doi.org/10.30892/auog.292111-818
\end{abstract}

\begin{abstract}
Through the study on the two depressions in the northern half of Mehedinţi County, we aimed to highlight the main characteristics of population evolution between 1912 and 2011, using data provided by INS Mehedinţi and Geographical Dictionary of Mehedinţi County published in 2011, have demonstrated four major geodemographic trends: the population of the two depressions registered higher values of demographic growth compared to the situation in the entire county, due mainly to city Drobeta Turnu Severin; the existence of two periods of evolution, a positive one until 1992, followed by a demographic decline that is and currently felt; the deeply rural population in Mehedinian Depression Corridor is experiencing a severe demographic decline; the urban population and the urban agglomeration of the city that includes most of the Severin Depression was protected from depopulation recorded in rural areas.
\end{abstract}

Key words: demographic, decline, Drobeta Turnu Severin, Danube, urban, rural

$$
* \quad * \quad * \quad * \quad * \quad *
$$

\section{INTRODUCTION}

Mehedinţean Depression Corridor and Severin Depression are located in the southwestern part of Romania, between the Coşuştei Hills in the east and the Mehedinţi Plateau to the west (Cucu and Cucu, 1980; Oglindoiu, 2010). In the south are bounded by the Danube River; The Bălciţei Piedmont, which together with the Coşuştei Hills and the two mehedinţi depressions are part of the Strehaia Piedmont which is a subdivision of the Getic Plateau and Flămânda Plain, a name given to the western part of the Blahniţa Plain, part of the Oltenia Plain, representing the western extremity of the Plain Romanian (Vîlcea, 2011; Badea and Dinu, 1974; Boengiu et al., 2012; Braghină, 2000). Within the Mehedinţi County, the two depressions are located on the surface of nine communes and the city of Drobeta Turnu Severin. The nine communes are from north to south: Bala, Şovarna, Ilovăţ, Sisesti, Malovăţ, Izvoru Bârzii, Brezniţa-Ocol, Şimian and Hinova (Ianoș and Iacob, 1980; Peptenatu, 2005). 


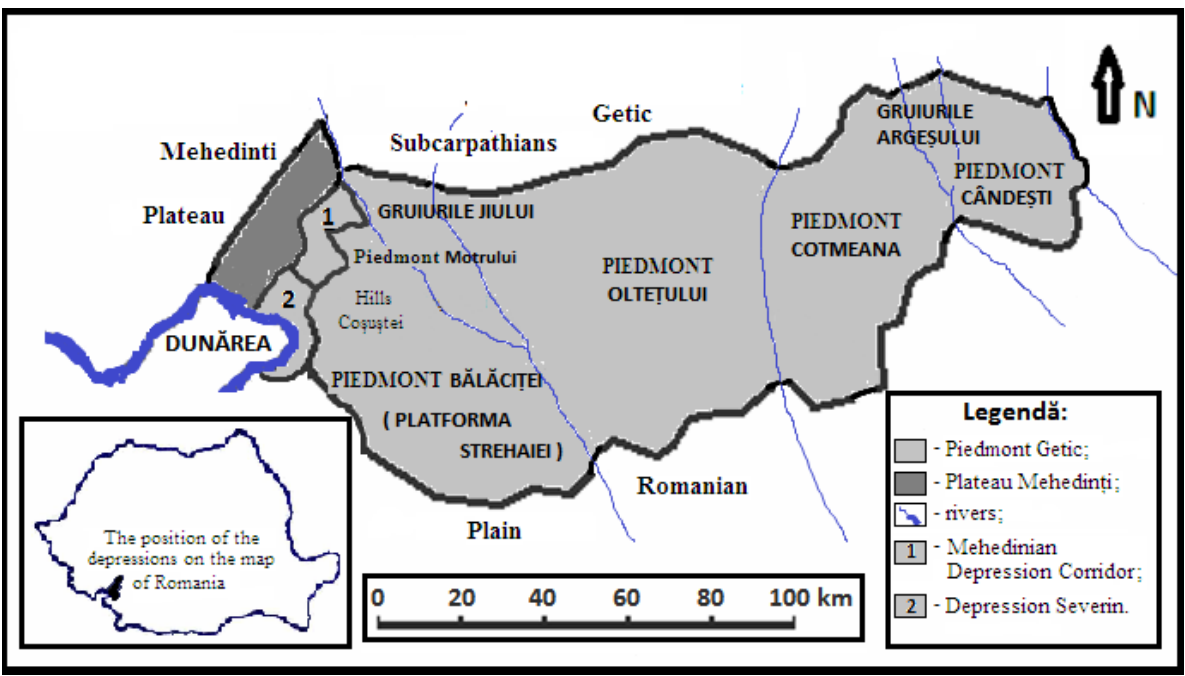

Figure 1. Mehedinţean Depression Corridor and Severin Depression within the Getic Plateau

For a clear understanding of the current demographic situation as well as the evolution over time, a comparison was made with the demographic situation of Mehedinţi County as a whole, thus arriving at new information that brings clarifications in the determination of the present state, highlighting both the rapid increases of the population as well as demographic decline, including in urban or rural areas.

Although there are well-known geographic works that analyze the demographic situation of Mehedinţi County as the works written by Vasile Cucu and Ana Popova Cucu in 1980 or the work written by Stroe Răsvan and Daniel Peptenatu in 2011, there are no extensive works to be carried out strictly on the depression area in the northern half of Mehedinţi County.

\section{METHODOLOGY}

The quantitative data were taken from the censuses of the population over the years from 1912 to 2011, provided by the County Mehedinti County Department of Statistics, but a special importance of the work published in 2011 by Razvan Stroe and Daniel Peptenatu: Geographic Dictionary of Mehedinţi County, which represents a wide demographic stigma on every locality or administrative area, with accurate and well documented data.

Through various mathematical and geographic calculations, the settlement of human settlements according to certain criteria, as well as the modeling of maps and sketches representative of the resulting data, or highlighted several trends that highlight two types of demographic evolution, one that is protected by the demographic decline specific to the city's surroundings Drobeta Turnu Severin, approaching the Danube, which includes much of the Depression of Sevrerin and one remote from the urban environment and the Danube River, which includes most of the Mehedinian Depression Corridor in a critical demographic decline.

\section{RESULTS AND DISCUSSIONS}

Evolution of the population of the two depressions compared to the demographic situation of Mehedinţi County

Mehedinian Depression Corridor and Severin Depression accommodate 47\% of the entire population of Mehedinţi County, on an area of only $13 \%$ of the county. With a total population of 265,000 inhabitants in 2011, the number of inhabitants of the region is in a slight demographic decrease, lower than the decline registered at the county level, due to the evolution of the population in Drobeta Turnu Severin and the localities is located in its neighborhood. 
Thanks to a sustained migration, originating in the plateau and plains areas which target the industrial area of Drobeta Turnu Severin, the population of the depressions held more and more percentages of the entire population of the county, which evolved from $44.7 \%$ in the year 1992 to $45.0 \%$ in 2002 and to $46.5 \%$ in 2011 (Peptenatu, 2005; Erdeli, 1998; Peptenatu and Braghină, 2006; Erdeli, 1983).

The total population of the two depressions increased steadily between 1912 and 1992, evolving from 60,000 inhabitants in 1912 to more than double, reaching the threshold of 150,000 inhabitants. After 1992, the population began to decline by losing to 10,000 inhabitants by 2002 , followed by a decrease of 15,000 by 2011 . In total there was a loss of 25,300 inhabitants in only 19 years, out of a total of 70,000 inhabitants as was the total demographic decline in the whole Mehedinti County in the same period.

\section{Evolution of population on relief units}

The dynamics of the population on the two relief units saw great differences between Severin Depression and Mehedinian Depression Corridor. If the population of the Depression of Severin was only three times larger than the population of the Mehedinian depression corridor at the level of 1912, until 2011 Depression Severin reaches 13 times the population.

Table 1. Evolution of the population on different categories in the Severin Depression and the Mehedinian Depression Corridor, between 1912 and 2011

(Source: Data processed by: Proiectul Universității București-1365, 2011; I.N.S. Mehedinți; Stroe and Peptenatu, 2011)

\begin{tabular}{|c|l|c|c|c|c|c|}
\hline No. & Year & 1912 & 1992 & 2002 & 2011 & $\begin{array}{c}\text { Population evolution } \\
1912-2011(\%)\end{array}$ \\
\hline 1 & Total population & 60.502 & 148.834 & 137.939 & 123.483 & +104 \\
\hline 2 & Urban population & 25.463 & 115.259 & 104.557 & 92.608 & +263 \\
\hline 3 & $\begin{array}{l}\text { Only the city } \\
\text { Drobeta Turnu Severin }\end{array}$ & 23.463 & 108.204 & 96.859 & 84.867 & +261 \\
\hline 4 & Rural population & 35.039 & 33.575 & 33.379 & 30.875 & -12 \\
\hline 5 & $\begin{array}{l}\text { Rural / total population } \\
\text { Mehedințean Depression } \\
\text { Corridor }\end{array}$ & 15.765 & 10.860 & 10.526 & 9.034 & -43 \\
\hline 6 & $\begin{array}{l}\text { Rural population } \\
\text { Depression of Severin }\end{array}$ & 19.274 & 22.715 & 22.853 & 21.841 & +13 \\
\hline 7 & $\begin{array}{l}\text { Total population } \\
\text { Depression of Severin }\end{array}$ & 44.734 & 137.974 & 127.413 & 114.449 & +156 \\
\hline 8 & Degree of urbanization $(\%)$ & 42,08 & 77,44 & 75,79 & 74,99 & \\
\hline
\end{tabular}

The southern half of the Mehedinti depression, which is represented by the Severin Depression, registered a growth rate of the net population higher than the situation recorded in the north. Also, the population in the Mehedintian Depression Corridor declined to the level of 2011, only half of the population in 1912. In contrast, the Severin Depression experienced a demographic explosion at the same time, its population being $150 \%$ higher than he held in 1912 . This means, on average, that the settlements halved their population in the Mehedintian Depression Corridor and rose once and a half in the Severin Depression at the same time. If by 1992 the population increased in the southern and urban areas and fell to the north, after this year the whole population decreased by 25,000 people. Of these, in the Mehedinian Depression Corridor, the loss was almost 2,000, and in the Depression of Severin the decrease was 23,000, more than 11 times the decrease in the northern half. In the Mehedinian Depression Corridor, on the surface of which there are four communes: Bala, Şovarna, Ilovăţ and Şişeşti, it was 100 years ago the double the population present, but the current censuses of the stable population included the inhabitants who have their domicile four communes, but they live and work in other areas such as Drobeta Turnu Severin, Timisoara, Motru or Bucharest, but also in Central- 
Western Europe, which means that the actual population of the settlements was in 1912 maybe over three or more numerous than the population permanently living in this depression at present (Diaconescu and Lung, 2018; Peptenatu et al., 2012).

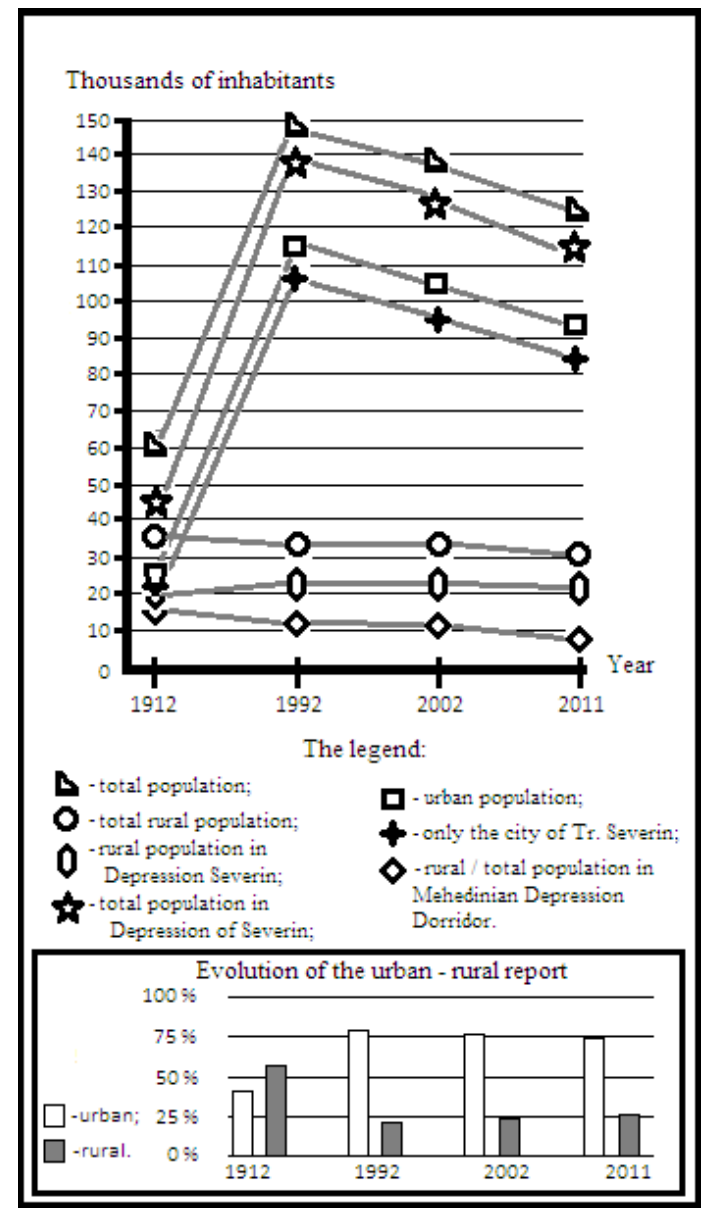

Figure 2. Variation in the number of populations by different categories and urban - rural ratio, between 1912 and 2011

(Source: Data processed by: Proiectul Universităţii București- 1365, 2011; I.N.S. Mehedinți; Stroe and Peptenatu, 2011; Stroe et al., 2008)

\section{Evolution of the population by administrative units}

The population of Mehedinti depression experienced a marked demographic increase until 1992, after which an ever more pronounced decline. However, the evolution of the population by administrative units reveals demographic features that are difficult to distinguish on a large scale.

At the level of 1912 the most populous commune was Bala with 6,000 people followed by Malovăţ commune with 5,000 and Sisesti with almost 4,700 inhabitants, the other communes having less than 4,000 inhabitants (Erdeli and Gheorghe, 1979; Peptenatu, 2003). At that time, the nine communes owned 11,000 more people than Drobeta Turnu Severin. Until the year 1992, the most populated ones are: Şimian with 9,000 inhabitants, Bala commune with less than 5,000 inhabitants and Brezniţa Ocol commune with over 4,000 inhabitants. Communes in the Depression of Severin become more and more populated in relation to the settlements in the 
Mehedinţean Depression Corridor, and the Municipality of Drobeta Turnu Severin reaches and even exceeds the population of the 9 communes with a total of 82,000 inhabitants. After 1992, the entire population of depressions declined steadily with a slight return due to migration from the adjacent relief units. At the level of the administrative units, four communes face a continuous demographic decline: Şovarna, Ilovăţ, Şişeşti and Malovat, three of which are located in the Mehedinti Depression Corridor. In only three administrative units, demographic growth is projected after 2011: Drobeta Turnu Severin and Hinova and Izvoru Bârzii communes. The commune of Bala registered an increase of the population between 1992 and 2002, and in the communes of Breznita-Ocol and Şimian, the population increased between 1992 and 2002 followed by a new period of growth after 2011. In the administrative units remote from the city of Dr. Tr. Severin, the population is in a vertiginous demographic decline, instead there is a stagnation and even a demographic increase in the town and the neighboring communes.

Table 2. Evolution of the population by administrative units between 1912 and 2017

(Source: I.N.S. Mehedinți; Stroe and Peptenatu, 2011; Ghinea, 2000; Diaconescu, 2013; Cucu et al., 1981)

\begin{tabular}{|c|c|c|c|c|c|c|}
\hline No. & $\begin{array}{c}\text { Unites } \\
\text { Administrativ }\end{array}$ & $\mathbf{1 9 1 2}$ & $\mathbf{1 9 9 2}$ & $\mathbf{2 0 0 2}$ & $\mathbf{2 0 1 1}$ & $\begin{array}{c}\mathbf{2 0 1 7} \\
\text { (estimate: } \\
\text { 1 July) }\end{array}$ \\
\hline 1 & Bala & 5.773 & 4.682 & 4.759 & 3.963 & 3.714 \\
\hline 2 & Șovarna & 2.523 & 1.532 & 1.415 & 1.270 & 1.091 \\
\hline 3 & Ilovăț & 3.790 & 1.744 & 1.580 & 1.291 & 1.207 \\
\hline 4 & Șișești & 4.681 & 3.469 & 3.210 & 2.959 & 2.583 \\
\hline 5 & Malovăț & 5.350 & 3.261 & 3.005 & 2.780 & 2.605 \\
\hline 6 & Izvoru Bârzii & 3.661 & 3.600 & 3.164 & 2.703 & 2.784 \\
\hline 7 & Breznița-Ocol & 3.693 & 3.231 & 4.123 & 3.859 & 3.981 \\
\hline 8 & Șimian & 3.732 & 8.714 & 9.670 & 9.650 & 10.316 \\
\hline 9 & Hinova & 3.241 & 2.903 & 2.865 & 2.849 & 2.891 \\
\hline 10 & Total comune & 36.444 & 33.136 & 33.796 & 31.324 & 31.171 \\
\hline 11 & Dr. Tr. Severin & 25.463 & 115.259 & 104.557 & 92.617 & 108.063 \\
\hline 12 & Total & 61.907 & 148.395 & 138.353 & 123.941 & 139.236 \\
\hline
\end{tabular}

The population of the communes decreased between 1912 and 2017 with: 2,000 inhabitants in the commune of Bala, 1,500 inhabitants in the commune of Şovarna, 2,500 inhabitants in Ilovăţ commune, 2,100 inhabitants in the commune of Şeşesti, 2,700 inhabitants in the commune of Malovăţ, 1,000 inhabitants in the commune Izvoru Bârzii and 300 inhabitants in the Hinova village. Demographic growth between 1912 and 2017 was recorded in the administrative units: Breznita-Ocol with an additional 300 people, Simian with 7,000 inhabitants and Drobeta Turnu Severin with 83,000 more inhabitants.

\section{Evolution of the settlements population}

To highlight how the population of human settlements evolved, we took the difference between the years from 1912 to 2011.

Very different values were found, ranging from $+624.29 \%$ to $-86.70 \%$. There are two categories of demographic evolution, growth and the decreasing number of the population.

Growth intervals:

- between 0 and +10\%: Câmpu Mare (1,98\%); Schinteiești (6,06\%); Halânga (7,41\%).

- $+10 \%$ and $+50 \%$ : Poroina $(27,86 \%)$; Noapteșa $(29,47 \%)$; Cârşu $(29,56 \%)$.

- $+50 \%$ and $+100 \%$ : Breznița-Ocol (50,13\%); Dudașu Schelei (62,10\%); Magheru $(98,68 \%)$.

- +100\% and +200\%: Dedovița Nouă (1948) (166,66\%); Gura Văii (170,97\%); Șimian (179,36\%).

- over 200\%: Drobeta Turnu Severin (285,75\%); Dudașu (328,33\%); Schela Cladovei (564,48\%); Cerneți $(624,29 \%)$. 
Decrease ranges:

- between 0 and -10\%: Bala de Sus (-1,95\%); Bistrița (-2,42\%); Balotești $(-4,13 \%)$; Hinova $(-9,62 \%)$.

- -10\% and $-30 \%$ : Izvoru Bârzii (-10,49\%); Malovăț (-13,13\%); Sărdănești $(-18,04 \%)$; Jidoștiţa (-20,07\%); Ostrovu Corbului (-21,65\%); Crainici $(-22,56 \%)$; Cocorova $(-22,68 \%)$; Bala (-25,33\%); Molani $(-27,11)$.

- -30\% and -50\%: Rudina (-30,42); 23 August (-35,64\%); Vidimirești (-36,82); Colibași $(-37,19 \%)$; Șișești $(-43,02 \%)$; Valea Copcii $(-43,29 \%)$; Brativoiești (-45,42\%); Dâlma (45,96\%); Puținei (-46,45\%); Erghevița (-46,65\%); Ohaba (-47,69\%); Șovarna $(-47,84 \%)$; Brateșul $(-48,55)$; Ciovârnășani $(-48,97 \%)$.

- -50\% and -70\%: Iupca (-51,66\%); Runcușoru (-52,89\%); Cărămidaru (-53,14\%); Schitul Topolniței (-53,54\%); Dâlbocița (-54,96\%); Crăguiești $(-55,43 \%)$; Comănești $(-57,62 \%)$; Cracu Lung (-57,96\%); Răscolești (-58,72\%); Ilovăț (-60\%); Bârda (-60,45\%); Studina (-60,59\%); Bobaița (-65,15\%); Negrești (-67,07\%).

- over - 70\%: Racova (-75\%); Budinești (-76,41\%); Șușiţa (-77,34\%); Lazu (-79,53\%); Firizu (-84,18\%); Dedovița Veche (-85,86\%); Cârjei (-86,70\%).

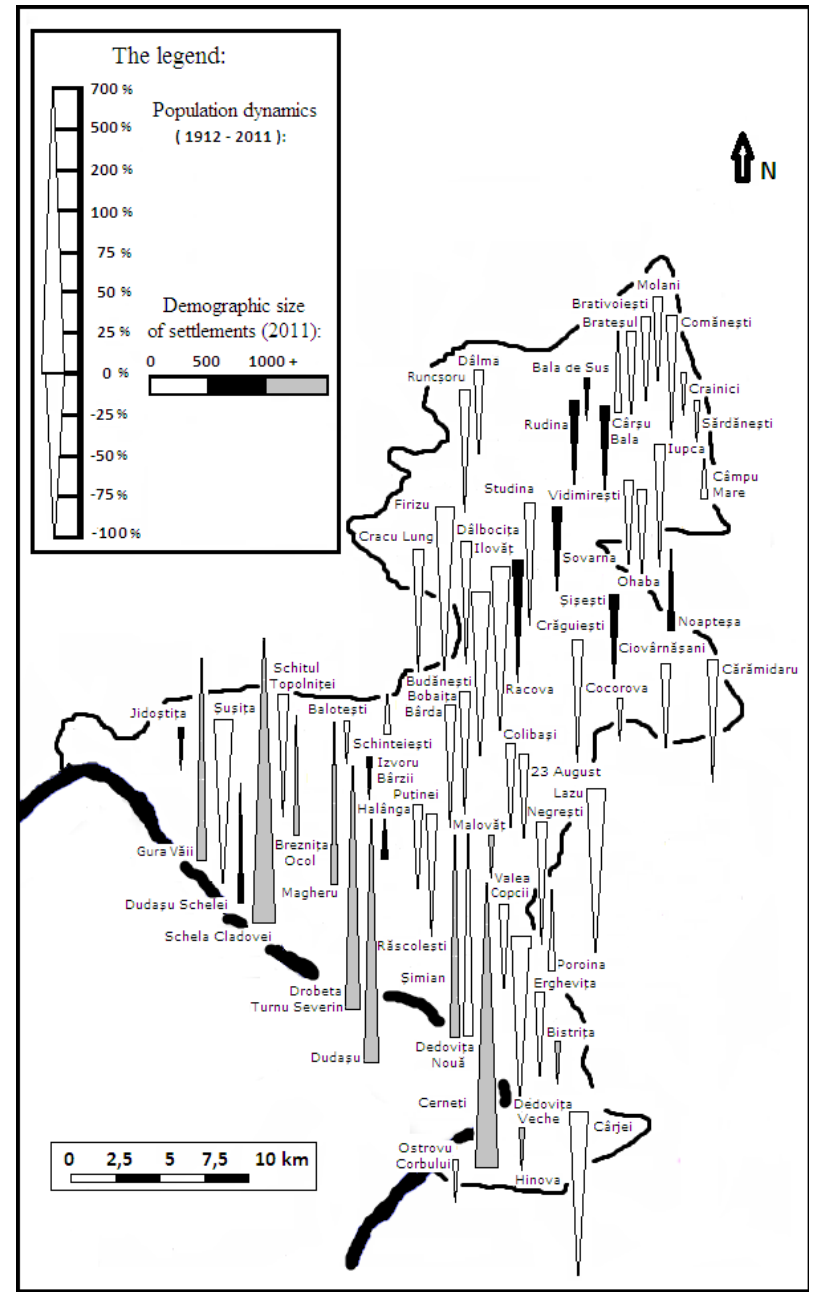

Figure 3. Demographic dynamics of settlements between 1912 and 2011

(Source: processed after: Proiectul Universității București- 1365, 2011; I.N.S. Mehedinți; Stroe and Peptenatu, 2011) 
Between 1912 and 2011, the population of the two depressions increased by $100.0 \%$, the evolution mainly due to Drobeta Turnu Severin with $285 \%$, as well as of neighboring localities: Dudașu (328\%); Schela Cladovei (564\%); Cerneți (624\%); Dedovița Nouă (1948) (166\%); Gura Văii (170\%); Șimian (179\%); Breznița-Ocol (50\%); Dudașu Schelei (62\%); Magheru (98\%); Schinteiești $(6 \%)$; Halânga (7\%). In addition to these human settlements, four other localities experienced population growth in the given interval, influenced by access to infrastructure (Câmpu Mare - 2\%, Poroina - 27\%), mining (Noapteşa - 29\%) or near the spa resorts 29\% (Cârşu, located near the balneoclimatic resort of Bala local interest) (Ianoș and Iacob, 1979). Of a total of 64 settlements located in the Mehedinti depressions, only 16 have registered population growth and managed to double the population of the two depressions.

The other 48 settlements, generally located at distant distances from the urban area and with poor infrastructure, have experienced population decreases, which lead to its half-life or exceed $70 \%$ of the local population 99 years ago, with the issue of dismantling or merging them. It highlights a positive demographic area that is limited to the urban environment and the surroundings of Drobeta Turnu Severin, an area with a low demographic decline the Danube meadow and in the low a Severin Depression and the Mehedintian Depression Corridor and a critical area of a shrinking demographic decline that includes in particular the deeply rural periphery dominated by the hilly villages (Olaru and Iordache, 2000; Lung and Diaconescu, 2019; Mazilu and Severineanu, 2007).

\section{CONCLUSIONS}

Between 1912 and 2011, the population of the two Mehedinti depressions doubled, being a sub-period of growth between 1912 and 1992 and a period of demographic decline between 1992 and 2011, except for the settlements near Drobeta Turnu Severin. Also, there is a clear differentiation between the two depressions and the entire Mehedinti County in favor of the first one due mainly to the demographic evolution of the city, but also a great difference between the two depressions, thus the Mehedintian Depressionary Corridor is in a continuous demographic decline on the whole period studied, during which the population of the Severin Depression experienced a real demographic explosion until 1992, following a decrease easier. Another major differentiation is given by the urban environment and the rural environment, so in the town of Drobeta Turnu Severin and the adjacent localities that can be considered as part of its urban agglomeration, the population experienced the highest population growths on the entire area of Mehedinţi County, time where the rural population is experiencing population aging, strong emigration and low fertility, being in a severe decline.

\section{REFERENCES}

Badea, L., \& Dinu, M. (1974). Depresiunile de contact din estul Podișului Mehedinți (Contact depressions in the eastern Mehedinti Plateau), SSGGG, Geografie XXI, nr. 2, București.

Boengiu, S., Vladut, A., \& Marinescu, E. (2012). Conditions of gully development within piedmont areas with examples from the western part of the Getic Piedmont, Romania. Journal of environmental biology, 33(2), 407-415.

Braghină, C. (2000). Asezarile umane din dealurile piemontane dintre Motru si Gilort: populatie, economie, organizarea spatiului. Editura Tehnica, București.

Diaconescu, L. (2013). Riscuri și hazarde naturale - sectorul depresionar Bala-Șovarna (Risks and natural hazards - the depressions sector of Bala-Sovarna), Editura Damira, Dr. Tr. Severin.

Diaconescu, L., \& Lung, M.-S. (2018). Power of big cities. Revista Română de Geografie Politică, 20(2), 67-75.

Cucu, V., \& Cucu, A.P. (1980). Județul Mehedinți (County of Mehedinti), Institutul de Geografie, Editura Academiei R.S.R., București.

Cucu, V., Erdeli, G., Popescu, E., \& Davidescu, M. (1981). Județul Mehedinți, colecția județelor patriei (Mehedinti County, the collection the counties of the country), Editura Turism, București.

Erdeli, G. (1998). Podișul Mehedinți, Geografie Umană (Mehedinţi Plateau, Human Geography), Editura Metropol, București.

Erdeli, G. (1983). Așezările omenești din Podișul Mehedinți. Aspecte de geografie istorică (The human settlements in the Mehedinti Plateau. Aspects of historical geography), Terra 1, București.

Erdeli, G., \& Gheorghe, I. (1979). Considerații geografice asupra așezărilor omenești din Piemontul Strehaia (Geographical considerations on Human Settlements in Strehaia Piedmont). Analele Universității din București, XXVIII, București. 
Ghinea, D. (2000). Enciclopedia geografică a României (The geographical encyclopedia of Romania), Editura Enciclopedică, București.

Ianoș, I., \& Iacob, G. (1979). Aspecte geografice privind sistematizarea teritoriului și localităților rurale din județul Mehedinți (Geographical aspects of spatial systematization rural settlements in Mehedinţi County). Analele Universității din București, Geologie-Geografie, XXVIII, 33-39.

Ianoș, I., \& Iacob, G. (1980). Probleme privind organizarea spațiului din bazinul Coșuștea (Issues related to organizing space in basin Cosuştea). Analele Universității din București, Geografie, XXIX, 97-102.

Lung, M.S., \& Diaconescu, L. (2019). Altitudinal distribution of population and settlements in the Carpathian Mountain space. Case study: Romanian Carpathians. Revista Română de Geografie Politică, 21(1), 1-17.

Mazilu, M.E., \& Severineanu, R. (2007). The tourism in Mehedinti County keeping pace with the European Integration, Analele Universităţii din Oradea, Stiiinţe Economice, 16(1), 1183-1185.

Oglindoiu, A.M. (2010). Podișul Piemontan al Bălăciței, geografia așezărilor rurale (Piedmont plateau of Bălăciţei, geography of rural settlements), Editura Aius Printed, Craiova.

Olaru, M., \& Iordache C. (2000). Tipologia habitatului rural din Defileul Dunării după potențialul turistic (Typology of rural habitat in Danube Delta after tourist potential). Geocarpatica. Analele Universității Creștine „,Dimitrie Cantemir", Revistă Geografică, anul III, nr. 2, Sibiu.

Peptenatu, D. (2011). Proiectul Universității București- 1365: Managementul teritorial bazat pe teoria polilor de creștere și Dezvoltarea teoriei contextului dinamic prin analiza impactului aridizării asupra economiei locale (University of Bucharest Project - 1365: Territorial Management based on pole growth theory and Dynamic context theory development by analyzing the impact of aridization on the local economy), București.

Peptenatu, D., \& Braghină, C. (2006). Evaluarea riscului și dezvoltarea teritorială. Studiu de caz Dealurile Coșuștei (Risk assessment and territorial development. Case Study Coşuştei Hills), Terra XXXV, Editura Societăţii de Geografie, București.

Peptenatu, D. (2003). Potenţialul de habitat al reliefului din Dealurile Coşuştei (Habitat potential of the relief in Coşuştei Hills), Comunicări de geografie, VII, Editura Universităţii din Bucureşti.

Peptenatu, D. (2005). Studiul geografic al așezărilor umane din Dealurile Coșuștei (Geographic study of the human settlements in the Coşuştei Hills), Teză de doctora, Universitatea din București.

Peptenatu, D., Pintilii, R., Draghici, C., \& Peptenatu, A. (2012). The efficiency of polycentric development strategies in the context of economic crisis. Case study-the development of Southwest Oltenia region-Romania. Bulletin of Geography. Socio-economic series, 17(17), 117-125.

Stroe, R., \& Peptenatu, D. (2011). Dicționarul geografic al județului Mehedinți (Geographical Dictionary of Mehedinţi County), Editura Fundației „Scrisul Românesc”, Craiova.

Stroe, R., Peptenatu, D., \& Erdeli, G. (2008). Dicţionarul Geografic al Judeţului Mehedinţi (Geographical Dictionary of Mehedinţi County), Editura Universitară, București.

Vîlcea, I.C. (2011). Țara Severinului. Studiu de geografie regională (The Land of Severin. Regional Geography Study). Teză de doctorat, Universitatea „Babeș-Bolyai”, Cluj-Napoca.

*** Institutul Național de Statistică: Direcția Județeană se Statistică Mehedinți (1912-2017). Recensământul Populației și al Locuințelor: Județul Mehedinți (Census of Population and Housing: Mehedinti County), Drobeta Turnu Severin.

Submitted:

June 02, 2019
Revised:

September 03, 2019
Accepted and published online

Octomber 30, 2019 